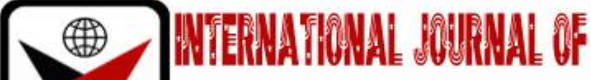

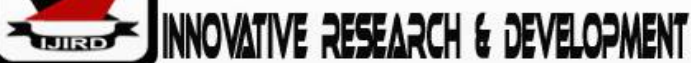

ISSN 2278 - 0211 (Online)

\section{Fertility of Soil in the Southern Zone of Gombe State, Nigeria}

\begin{tabular}{c}
\hline Babaji,G.A \\
Professor, Department of Soil Science, \\
Abubakaar Tafawa Balewa University, Nigeria \\
Hassan,A.M. \\
Professor, Department of Soil Science, \\
Abubakar Tafawa Balewa University, Nigeria \\
Jauro,A.G. \\
Principal Research Officer, Department of Silviculture \\
Forestry Research Institute of Nigeria, Nigeria \\
Nwafor,E.0. \\
Principal Research Officer, Department of Agronomy \\
Forestry Research Institute of Nigeria, Nigeria \\
\hline
\end{tabular}

\section{Abstract:}

The fertility status of soils in the southern zone of Gombe state was assessed. The study areas were Ayaba, Tula Wange, Tundu Bilhri, Pamadu Shongom, Dogon Ruwa and Gelengu. Within 24-84\% sand, 3-47\% salt and 8-32\% clay in the 0$15 \mathrm{~cm}$, the soils were dominantly sandy loam with exception of Tudu Bulhri that is loamy sand in Texture. As for fertility status (values in $\mathrm{mg} / \mathrm{kg}^{-1}$ ) The soils were rated low in total $\mathrm{N}$ (0.04-0.18 mean 0.10), Organic Carbon (C) (0.28-1.45 mean 0.84) and Based saturation (23-73 mean 46\%) with exception of Ayaba and Tula Wange that are in medium limit, low to medium CEC (Values in C Mol(+)kg) ranged from (4.44-19.40 men 9.58), Medium in Ca (1.26-495 mean 2.84), Mg (0.431.21 mean 0.77), K(0.14-0.42 mean 0.25) and Available Phosphorus (8.70-38.85 mean 19.21). Appropriate application of manure/ fertilizer - $\mathrm{N}$ may be necessary for productivity.

Keywords: Fertility status, Fadama soils and chemical properties

\section{Introduction}

Irrigated farming depends on soil quality which is an assessment of how well soil exhibit all of its functions now and how those functions are being preserved for future use. It cannot be determined by measuring only crop yield, water quality or any other single outcome. Soil quality cannot be measured directly, so we evaluate indicators. Indicators are measurable properties of soil or plants that provide clues about how well the soil can function. Indicators can be physical, chemical and Biological properties, processes or visual features of plants (Karlen et al, 2008.)

The concepts of soil quality and soil assessment are highly contentious within the soilscience commonly because many believes those terms have generated and over simplified the collective knowledge and wisdom developed. Through several centuries of intensive, in depth global studies of soil resources (Letey et al. 2003).

\section{Study Area}

Southern zone of Gombe state located between latitude $9^{\circ} 30^{\prime}$ and 12o $30^{\prime}$ and longitudes $8^{\circ} 45^{\prime}$ and $11^{\circ}$ 45 $^{\prime}$ E of the Greenwich Meridian. It lies within the North East region of Nigeria, Southern zone shares boundaries with Adamawa and Taraba states to the south and Bauchi state to the West. The selected fadama farms for this study are Dogon Ruwa, Gelengu, Pamadu Shongom, Tudu Bilhri and Tula Wange irrigated Fadama farm lands of Gombe state shown in map 1. 


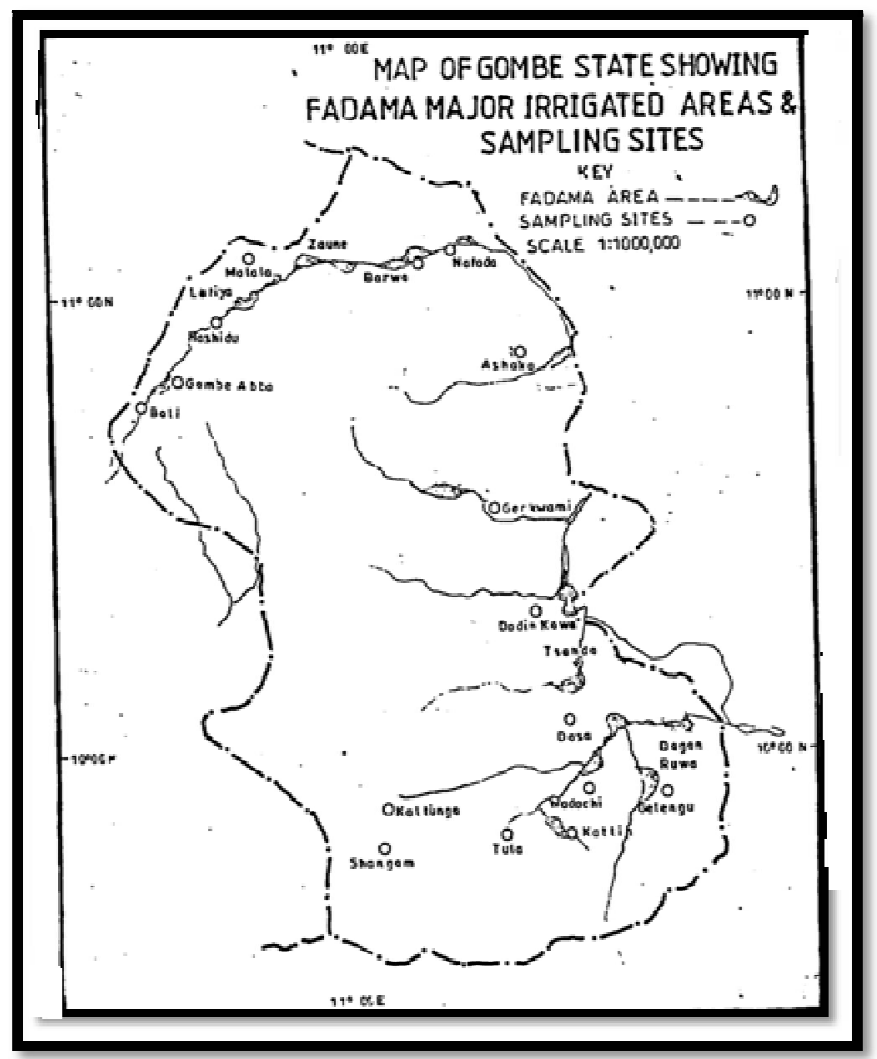

Figure 1: Map of Sampling Spot

\section{SOIL Sampling}

Twenty-four systematic random composite soil samples were collected at the depth of $0-15 \mathrm{~cm}$, four(4) each from the study areas. These samples were air dried, grounded using porcelain pestle and mortar and passed through $2 \mathrm{~mm}$ sieve. The sieved soil samples were stored and was analysed in the laboratory.

\section{Laboratory Soil Analysis}

The processed soil samples were analysed for physic chemical properties. The particle size distribution was determined by the Bonyoncus by hydrometer method and the texture was asses on the U.S.D.A. textual triangle. Organic Carbon (C)was determined by wet oxidation method (Juo, 1979), total Nitrogen was determined by the micro Khadahl method as was presented by (Juo,1979) and available phosphorus was extracted by Bray-1 method and was read on a spectrophotometer. Cation Exchange Capacity (CEC) were determined by $\mathrm{NH}_{4} \mathrm{AC}$ saturation method (Chapman, 1965). Exchangeable bases were determined from the result for the CEC determination. Bases saturation was computed as follows: -

$\mathrm{BS}=\frac{\mathrm{Ca}^{++}+\mathrm{Mg}^{++}+\mathrm{K}^{+}+\mathrm{Na}^{+}}{\mathrm{CEC}} \times 100$

page etal (1985)

Soil PH were determined in 1.1 soil: water using a caromel electrode PH meter (Smith 1(83).

Electric Conductivity (EC) was determined in 1.5 soil water extract on a conductivity meter. The value is multiplied by a factor (6.4) to obtain the ECe saturated extract (Landon, 1991). Exchangeable sodium percentage ESP was calculated using the formula as follows: -

$\mathrm{ESP}=\frac{N a^{+}}{C E C} \times 100$

\section{Data Analysis}

Data obtained were subjected to descriptive statistical analysis, coefficient of variance (CV) was used to test for dispersion of data using S.P.S.S (25) (2017) statistical package.

\section{Results and Discussion}

\subsection{Particle Size Distribution (PSD)}

The overall soil texture of southern Gombe soils ranges from 24.08-84.08 (mean 68.44\%) sand, 3.2- 47.28 (mean $18.22 \%$ ) soil and 8.64-32.64 (mean 13.34\%) clay was shown in table 1. Can be describe as sandy loamy in most of the areas except in Tudu Bilhri that is loamy sand.

\subsection{Nitrogen Fertility}

Ranges (in $\mathrm{Mg} / \mathrm{Kg}^{-1}$ ) of total Nitrogen content in $0-15 \mathrm{~cm}$ soil depth were $0.04-18$ (mean 0.10 ) $\mathrm{N}$ in the study areas. These indicate low Nitrogen fertility status, this conforms with general characteristics low total Nitrogen in the 
Savannah soils (Jones and Wild, 1975; Kowal and Kassam, 1978). Esu et al, (1991) set low, medium and high fertility category limits with total $\mathrm{N}$ ranging from $<0.0 .15,0-15-0.20$ and $>0.2$ respectively. Soil ranged $0.04-1.10(\mathrm{Mg} / \mathrm{Kg}-1) \mathrm{in}$ southern zone of Gombe state irrigated fedama lands were categorised as low Nitrogen (N) Fertility status.

\subsection{Organic Carbon}

Table 2 shows that the organic Carbon content in the soils were low, with (values in $\mathrm{Mg} / \mathrm{Kg}^{-1}$ ) ranges from 0.28 1.45(mean 0.84) in the southern zone this can be compared with $0.5-1.2 \mathrm{Mg} / \mathrm{Kg}^{-1}$ reported by Webster and Wilson (1980) for some West African hydromorphic fadama soils.

\subsection{Cation Exchange Capacity}

The soils in the southern zone of Gombe state varied within the ranged 4.44-19.40 (mean 9.58 values in $\mathrm{cmol} / \mathrm{kg}$ ) with low CEC in Ayaba and some part of Tula wange and moderate to high in most location. This is based on the limit $\varangle 6$, 6-12 and >12 CMol (+) Kg for low, medium and high categories respectively, as set by Adepetu et al (1979).

\subsection{Available Phosphorus Fertility}

Generally, the content of available phosphorus in southern zone of Gombe state fadama lands is quite low with range .8.70-38.35 (mean $19.29 \mathrm{mg} / \mathrm{kg}$ ) in 0-15cm soil depth, considering results adopted for the Nigerian Savannah soils by Esu et al. (1991).

\subsection{Calcium, Magnesium and Potassium Fertility}

The bases in the southern zone of Gombe state is quite moderate in quantity although Calcium and Magnesium were the dominant bases. Esu et al. (1991). Set $<2,2-5$ and $>5$ (Ca), $\varangle 0.3,3-10$, and $>10$ (Mg) and $\varangle 0.15,0.15-0.30$ and $>0.30(\mathrm{~K})$ for low, medium and high contents for $\mathrm{Ca}, \mathrm{Mg}$ and $\mathrm{K}$ respectively.

\subsection{Base Saturation}

Base saturation was low in almost all the study location ranges (23-73 mean 46) with exception in Ayaba and Tula Wange ranges (54-73). That are in medium categories limit as set by Adepetu (1979) $<50,50-80$ and $>80$ for low medium and high base saturation.

\section{Conclusion}

This study indicates that the soils are dominantly sandy loam and loamy sand in Ayaba in Tudu Bilhri, low in total $\mathrm{N}$, organise $\mathrm{C}$ and base saturation, medium in $\mathrm{Ca}^{++}, \mathrm{Mg}^{++}, \mathrm{K}^{+}, \mathrm{CEC}$ and Available Phosphorus. Adequate application of manure or fertilizer may be necessary for amending deficiency.

\begin{tabular}{|c|c|c|c|c|c|c|}
\hline \multirow[t]{3}{*}{ S/ NO } & \multirow{2}{*}{$\begin{array}{l}\text { Description of } \\
\text { Sampling Spot }\end{array}$} & \multirow{2}{*}{$\begin{array}{l}\text { Number of } \\
\text { Samples }\end{array}$} & SAND & SILT & CLAY & \multirow[t]{2}{*}{ TEXTURE } \\
\hline & & & $\begin{array}{l}\text { Range } \\
\text { Mean }\end{array}$ & $\begin{array}{l}\text { Range } \\
\text { Mean }\end{array}$ & $\begin{array}{l}\text { Range } \\
\text { Mean }\end{array}$ & \\
\hline & Southern Zone & & & & & \\
\hline 12 & Ayaba & 4 & $\begin{array}{l}73.20- \\
83.20 \\
77.70\end{array}$ & $\begin{array}{c}7.44-11.44 \\
12.44\end{array}$ & $\begin{array}{c}9.36-11.36 \\
9.68\end{array}$ & SL \\
\hline 13 & Dogon Ruwa & 4 & $\begin{array}{l}63.20- \\
73.20 \\
70.20\end{array}$ & $\begin{array}{l}13.44- \\
19.44 \\
16.44\end{array}$ & $\begin{array}{l}11.36- \\
17.36 \\
13.36\end{array}$ & SL \\
\hline 14 & Gelengu & 4 & $\begin{array}{c}24.08- \\
84.08 \\
44.58\end{array}$ & $\begin{array}{c}3.28-47- \\
28 \\
33.78\end{array}$ & $\begin{array}{l}12.64- \\
32.36 \\
21.64\end{array}$ & SL \\
\hline 15 & $\begin{array}{l}\text { Pamadu } \\
\text { Shongom }\end{array}$ & 4 & $\begin{array}{l}60.08- \\
76.08 \\
66.08\end{array}$ & $\begin{array}{l}13.28- \\
27.28 \\
20.28\end{array}$ & $\begin{array}{l}10.64- \\
18.64 \\
13.64\end{array}$ & SL \\
\hline 16 & Tudu-Bilgiri & 4 & $\begin{array}{l}68.08- \\
82.08 \\
75.08\end{array}$ & $\begin{array}{c}5.28-17.28 \\
12.78\end{array}$ & $\begin{array}{c}8.64-14.64 \\
12.14\end{array}$ & LS \\
\hline \multirow[t]{4}{*}{17} & Wange-Tula & 4 & $\begin{array}{l}73.20- \\
83.20 \\
78.70\end{array}$ & $\begin{array}{c}7.44-17.44 \\
11.94\end{array}$ & $\begin{array}{c}9.36-9.36 \\
9.36\end{array}$ & SL \\
\hline & Total & \multirow[t]{3}{*}{24} & $\begin{array}{l}24.08- \\
84.08 \\
68.44\end{array}$ & $\begin{array}{c}3.28-47.28 \\
18.22\end{array}$ & $\begin{array}{c}8.64-32.64 \\
13.34\end{array}$ & \\
\hline & STD Error & & 3.55 & 2.54 & 1.22 & \\
\hline & C.V (\%) & & 24 & 66 & 43 & \\
\hline
\end{tabular}

Table 1: Particle Size Distribution of Irrigated Farms in Gombe State

KEY: SL = Sandy Loam, L=Loam, LS = Loamy Sa 


\begin{tabular}{|c|c|c|c|c|c|c|}
\hline \multirow[t]{2}{*}{ S/ NO } & \multirow{2}{*}{$\begin{array}{l}\text { Description of } \\
\text { Sampling Spot }\end{array}$} & \multirow{2}{*}{$\begin{array}{l}\text { Number } \\
\text { of } \\
\text { Samples }\end{array}$} & $\% \mathrm{OC}$ & TOTALN & $\mathbf{P}$ & \multirow{2}{*}{$\begin{array}{c}\text { Depth } \\
\text { (cm) }\end{array}$} \\
\hline & & & $\begin{array}{l}\text { Range } \\
\text { Mean }\end{array}$ & $\begin{array}{l}\text { Range } \\
\text { Mean }\end{array}$ & $\begin{array}{l}\text { Range } \\
\text { Mean }\end{array}$ & \\
\hline & Southern Zone & & & & & \\
\hline 13 & Ayaba & 4 & $\begin{array}{l}0.47- \\
0.56 \\
0.51\end{array}$ & $\begin{array}{c}0.06-0.07 \\
0.06\end{array}$ & $\begin{array}{l}17.33- \\
30.49 \\
23.40\end{array}$ & $0-15 \mathrm{~cm}$ \\
\hline 14 & Dogon-Ruwa & 4 & $\begin{array}{l}0.45- \\
0.73 \\
0.61 \\
\end{array}$ & $\begin{array}{c}0.07-0.10 \\
0.08\end{array}$ & $\begin{array}{l}10.12- \\
22.99 \\
13.64\end{array}$ & $0-15 \mathrm{~cm}$ \\
\hline 15 & Gelengu & 4 & $\begin{array}{l}0.82- \\
1.39 \\
1.12 \\
\end{array}$ & $\begin{array}{c}0.09-0.14 \\
0.11\end{array}$ & $\begin{array}{l}18.16- \\
22.72 \\
20.81 \\
\end{array}$ & $0-15 \mathrm{~cm}$ \\
\hline 16 & PamaduShongom & 4 & $\begin{array}{l}0.28- \\
1.12 \\
0.76\end{array}$ & $\begin{array}{c}0.04-0.14 \\
0.09\end{array}$ & $\begin{array}{l}12.10- \\
38.85 \\
26.86\end{array}$ & $0-15 \mathrm{~cm}$ \\
\hline 17 & Tudu-Bilhiri & 4 & $\begin{array}{l}0.84- \\
1.12 \\
0.94\end{array}$ & $\begin{array}{c}0.09-0.12 \\
0.10\end{array}$ & $\begin{array}{l}13.40- \\
20.48 \\
16.63\end{array}$ & $0-15 \mathrm{~cm}$ \\
\hline 18 & Wange-Tula & 4 & $\begin{array}{l}0.62- \\
1.45 \\
1.05\end{array}$ & $\begin{array}{c}0.08-0.18 \\
0.12\end{array}$ & $\begin{array}{l}8.70- \\
19.52 \\
13.94\end{array}$ & $0-15 \mathrm{~cm}$ \\
\hline & Total & 24 & $\begin{array}{l}0.28- \\
1.45 \\
0.84\end{array}$ & $\begin{array}{c}0.04-0.18 \\
0.10\end{array}$ & $\begin{array}{l}8.70- \\
38.85 \\
19.21\end{array}$ & \\
\hline & STD Error & & 0.07 & 0.01 & 1.64 & \\
\hline & C.V (\%) & & 36 & 33 & 39 & \\
\hline
\end{tabular}

Table 2: Total Nitrogen (N), Organic Carbon (C) and Available Phosphorus (P) $\mathrm{In}\left(\mathrm{Mg} / \mathrm{Kg}^{-1}\right)$ of Irrigatedfarms in Gombe State

\begin{tabular}{|c|c|c|c|c|c|c|c|c|}
\hline \multirow[t]{2}{*}{ S/ NO } & \multirow{2}{*}{$\begin{array}{l}\text { Description of } \\
\text { Sampling Spot }\end{array}$} & \multirow{2}{*}{$\begin{array}{l}\text { Number of } \\
\text { Samples }\end{array}$} & $\mathbf{K}^{+}$ & $\mathrm{Na}^{+}$ & $\mathrm{Ca}^{++}$ & $\mathrm{Mg}^{++}$ & CEC & \multirow{2}{*}{$\begin{array}{l}\text { Depth } \\
\text { (cm) }\end{array}$} \\
\hline & & & $\begin{array}{l}\text { Range } \\
\text { Mean }\end{array}$ & $\begin{array}{l}\text { Range } \\
\text { Mean }\end{array}$ & $\begin{array}{l}\text { Range } \\
\text { Mean }\end{array}$ & $\begin{array}{l}\text { Range } \\
\text { Mean }\end{array}$ & $\begin{array}{l}\text { Range } \\
\text { Mean }\end{array}$ & \\
\hline & Southern Zone & & & & & & & \\
\hline 13 & Ayaba & 4 & $\begin{array}{c}0.16- \\
0.20 \\
0.18\end{array}$ & $\begin{array}{c}0.10- \\
0.14 \\
0.11\end{array}$ & $\begin{array}{l}1.48- \\
1.86 \\
1.69\end{array}$ & $\begin{array}{c}0.43- \\
0.72 \\
0.59\end{array}$ & $\begin{array}{l}4.44- \\
5.21 \\
4.76\end{array}$ & $0-15 \mathrm{~cm}$ \\
\hline 14 & Dogon-Ruwa & 4 & $\begin{array}{c}0.14- \\
0.26 \\
0.19\end{array}$ & $\begin{array}{c}0.12- \\
0.16 \\
0.14\end{array}$ & $\begin{array}{l}1.95- \\
2.95 \\
2.39\end{array}$ & $\begin{array}{c}0.56- \\
1.14 \\
0.77\end{array}$ & $\begin{array}{c}6.32- \\
11.60 \\
8.98\end{array}$ & $0-15 \mathrm{~cm}$ \\
\hline 15 & Gelengu & 4 & $\begin{array}{l}0.13- \\
0.42 \\
0.14\end{array}$ & $\begin{array}{c}0.12- \\
0.16 \\
0.14\end{array}$ & $\begin{array}{l}3.75- \\
4.95 \\
4.46\end{array}$ & $\begin{array}{c}0.75- \\
1.21 \\
1.05\end{array}$ & $\begin{array}{l}7.29- \\
19.40 \\
16.03\end{array}$ & $0-15 \mathrm{~cm}$ \\
\hline 16 & $\begin{array}{l}\text { Pamadu } \\
\text { Shongom }\end{array}$ & 4 & $\begin{array}{l}0.14- \\
0.22 \\
0.18\end{array}$ & $\begin{array}{c}0.08- \\
0.12 \\
0.09\end{array}$ & $\begin{array}{l}1.26- \\
3.69 \\
2.54\end{array}$ & $\begin{array}{c}0.43- \\
0.89 \\
0.68\end{array}$ & $\begin{array}{c}6.64- \\
15-30 \\
10.88\end{array}$ & $0-15 \mathrm{~cm}$ \\
\hline 17 & Tudu-Bilhri & 4 & $\begin{array}{c}0.21- \\
0.28 \\
0.25\end{array}$ & $\begin{array}{c}0.10- \\
0.12 \\
0.11\end{array}$ & $\begin{array}{l}2.49- \\
3.33 \\
2.87\end{array}$ & $\begin{array}{c}0.76- \\
0.81 \\
0.75\end{array}$ & $\begin{array}{c}6.39- \\
14.80 \\
9.05\end{array}$ & $0-15 \mathrm{~cm}$ \\
\hline 18 & Wange-Tula & 4 & $\begin{array}{l}0.23- \\
0.25 \\
0.29\end{array}$ & $\begin{array}{c}0.09- \\
0.13 \\
0.11\end{array}$ & $\begin{array}{l}1.98- \\
3.75 \\
2.86\end{array}$ & $\begin{array}{c}0.65- \\
0.93 \\
0.81\end{array}$ & $\begin{array}{l}4.80- \\
9.63 \\
7.11\end{array}$ & $0-15 \mathrm{~cm}$ \\
\hline & Total & 24 & $\begin{array}{c}0.14- \\
0.42 \\
(0.25)\end{array}$ & $\begin{array}{c}0.08- \\
0.16 \\
(0.11)\end{array}$ & $\begin{array}{c}1.26- \\
4.95 \\
(2.84)\end{array}$ & $\begin{array}{c}0.43- \\
1.21 \\
(0.77)\end{array}$ & $\begin{array}{l}4.44- \\
19.40 \\
(9.58)\end{array}$ & \\
\hline & STD Error & & 0.02 & 0.004 & 0.23 & 0.05 & 1.05 & \\
\hline & C.V (\%) & & 33 & 17 & 38 & 28 & 51 & \\
\hline
\end{tabular}

Table 3: Exchangeable Bases and CEC of Irrigated Farm $\left(\mathrm{Cmol} / \mathrm{Kg}^{-1}\right)$ in Gombe State 


\section{References}

i. Adepetu, J.A.A., Adebayo, A.A., Aduap, A. and Aloia, C.O. (1979). A preliminary survey of fertility status of some soil in ondo state under traditional cultivation. Ife J. Agric. 135-149

ii. Jones, M.J. (1975). Soil of the West Africa Savannah. Technical communication No. 55, commonwealth Bureau of soils, Hapenden. pp. 9-50

iii. Juo, A.S. (1979). Selected methods forsoil and Plant Analysis. International Institute of Tropical Agriculture. Manuel Series. P.55.

iv. Karlen, D. L., Marsbach, M.J., Doran, J.W., Cline, R. G., Han-is, R. F. And Scbuman. G.E (1997). Soil Quality: A concept, definition, and framework for evaluation. Soil science- Amer.J. 61:4-10.

v. Karlen, D.L., Tomer, M.D., Neppel, J. And Cambardella, C.A. (2008). A preliminary Water Shed Scale Soil Quality Assessment in North Central IOWA, USA. Soil Tillage Res. 99: 291-299.

vi. Landon, J.R. (1991). Booker Tropical Soil Manual. Longman Scientific and Technology

vii. Letey, J., R.E., Upchurch, D.R., Cassel, D.K., Olson, K, R., Payne, W.A., Peterie, S.E, Price, G.H. Regmato, R.J., Scott, H.D., Smethrust, P.J. and Triplett, G.B. (2003). Deficiencies in the Soil Quality Concept and its Application. J. Soil Water Conservation, 58: 180-187.

viii. Lowdermilk, W.C. (1953) Conquest of the lane through Seven Thousand years. Agric, Bull. No. 99 U.S. Gov. Print Office Washington, D.C.

ix. Mustapha, S. (2000), Fertility Status and Productivity Constraints of the Basement Complex-derived Usults in Bauchi state, Nigeria. J. Agric. Technology, 11-19.

x. NRCS. (2011). Soil and Water Quality Measurement. East National Technology Support Centre, NRCS National Soil Survey Centre, ARS National Laboratory for Agriculture and the Environment, NCERA-59 Scientists, and Department of National Resources and Environmental Sciences, University of Illinios at Urbana-Champaign.

xi. Page, A.L., Miler, R.H. and Keeny, D.R. (1982). Methods of soil Analysis. Agric. ASA, Madison, Wisconsin, USA 9:2.

xii. Smith, J.L. and Doren, J.W. (1996). Measurement and use of PH Electrical Conductivity for soil Quality Analysis. Pp. 169-185. In J.W. Doran and A.J. No.49, Soil Science Society of American Inc. Madison. 